\begin{tabular}{|c|c|c|}
\hline$\exists$ & $\begin{array}{c}\text { International Journal of Current Research } \\
\text { and Academic Review }\end{array}$ & 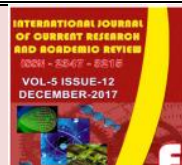 \\
\hline $\begin{array}{l}\text { EXCELLENT } \\
\text { PUBLISHERS }\end{array}$ & $\begin{array}{c}\text { ISSN: 2347-3215 (Online) } \\
\text { Journal homepage: http://www.ijcrar.com }\end{array}$ & \\
\hline
\end{tabular}

doi: https://doi.org/10.20546/ijcrar.2017.512.002

\title{
DPPH Radical Scavenging Activity of Ethanolic Leaf Extracts of Capparis sepiaria, Euphorbia heterophylla and Tamilnadia uliginosa
}

\author{
B. Kalpana ${ }^{1}$ and M. Prakash ${ }^{2} *$ \\ ${ }^{1}$ Research \& Development Centre, Bharathiar University, Coimbatore-641 046, Tamil Nadu, India \\ ${ }^{2}$ Department of Microbiology, Kanchi Shri Krishna College of Arts and Science, Kilambi, Kancheepuram-631 551, \\ Tamil Nadu, India \\ *Corresponding author
}

\begin{tabular}{|c|c|}
\hline Abstract & Article Info \\
\hline \multirow{6}{*}{$\begin{array}{l}\text { The present study has been carried out to investigate the presence of DPPH radical } \\
\text { scavenging activity of ethanolic crude leaf extracts of Capparis sepiaria, Euphorbia } \\
\text { heterophylla and Tamilnadia uliginosa. The leaves were collected, shade dried, } \\
\text { powdered and extracted with ethanol. The crude form of the leaf extracts were taken } \\
\text { for radical scavenging activity against free radical using a 2, 2-diphenyl-1- } \\
\text { picrylhydrazyl (DPPH) free radical activity. The results showed that in all the extracts, } \\
\text { the DPPH activity was found to be concentration dependent. At the concentration of } 75 \\
\mu 1 / \text { ml ethanol extract of Tamilnadia uliginosa yielded the highest radical scavenging } \\
\text { activity of } 77.6 \pm 4.5 \% \text {. Ethanol leaf extract of Tamilnadia uliginosa was found to } \\
\text { possess strong antioxidant activity assessed by means of DPPH activity. }\end{array}$} & $\begin{array}{l}\text { Accepted: } 28 \text { November } 2017 \\
\text { Available Online: } 20 \text { December } 2017\end{array}$ \\
\hline & Keywords \\
\hline & Antioxidant activity \\
\hline & \\
\hline & Leaf extracts \\
\hline & Radical scavenging \\
\hline
\end{tabular}

\section{Introduction}

Plants produce tens of thousands of different natural products also referred to as secondary metabolites. These metabolites were once consideration to be the result of unusual metabolism, or a form of passing storage of consequence and intermediates thereof. Although the true role of such metabolites in plants remains mostly unknown, it is evident that plants invest a great deal of resources in synthesizing, accumulating and sorting such metabolites, often produced through complex and highly regulated biosynthetic pathways operating in multiple cellular and sub-cellular compartments (Lewinsohn and Gijzen, 2009).

Antioxidants are reactive oxygen species (ROS), such as superoxide radical $\left(\mathrm{O}_{2}^{-}\right)$, hydroxyl radicals $\left(\mathrm{OH}^{-}\right)$and peroxyl radicals $\left(\mathrm{ROO}^{-}\right)$, are produced as a part of normal metabolic processes. The oxidative damages caused by ROS on lipids, proteins and nucleic acids may trigger various chronic diseases, such as coronary heart diseases, atherosclerosis, cancer and aging.

The health-promoting effect of antioxidants from plants is thought to arise from their protective effects by counteracting ROS. Indeed, epidemiological studies have demonstrated an inverse association between intake of fruits and vegetables and mortality from age-related diseases such as coronary heart diseases (Madhavi et al., 1996). Now a days, licorice is widely used for its antimicrobial, antioxidant, anti-inflammatory, anticoagulative, antiulcer, expectorant, antiallergic and anxiolytic activities and a number of other pharmacological actions (Khattak and Simpson, 2010). 
Plant materials contain active components, especially antioxidant components are present in unique plant group (Shyur et al., 2005).

Silva et al., (2005) was determined 14 species of plants belonging to four families, used for different food and medicinal purposes in Brazil, were evaluated for their capacity to inhibit the reduction of the free radical Five extracts, two from Lamiaceae family and three from Palmaceae family (Copernicia cerifera leaves and mesocarp of fruits and the endocarp/mesocarp of fruits from Orbignya speciosa) were able to increase the tolerance of $S$. cerevisiae to eukaryotic cell model cell line and showed to be active as DPPH radical scavengers, thus indicating that these plant extracts could be considered as potential sources of antioxidants.

With the exception of ethanol extract of $H$. fasciculata, the remainder four extracts exhibited a DPPH radical scavenging activity higher than that obtained from Ginkgo biloba, a reference plant with well documented antioxidant activity.

The plants selected for the present study, Capparis sepiaria, Euphorbia heterophylla and Tamilnadia uliginosa are known to possess various biological activities, antimicrobial and anti-inflammatory activity (Satyanarayana et al., 2010; Kalpana and Prakash, 2015 and 2016). The DPPH radical scavenging activity of the crude leaf extracts of these plants are required to strengthen their biological activities. The objective of this study is to determine the DPPH radical scavenging activity of the ethanolic crude leaf extracts of Capparis sepiaria, Euphorbia heterophylla and Tamilnadia uliginosa.

\section{Materials and Methods}

\section{Collection of leaves}

The leaves of the medicinal plants selected for the present study were collected from Sirumalai hills (Eastern Ghats), Dindigul, Tamil Nadu and the identification was confirmed using standard local floras (Gamble and Fischer, 1957; Matthews, 1983). The names of the plants identified were Capparis sepiaria L. (Capparaceae), Euphorbia heterophylla L. (Euphorbiaceae) and Tamilnadia uliginosa (Retz.) Tirveng. \& Sastre (Family: Rubiaceae). The leaves collected were shade dried and powdered using mortar and pastle. A fine powder obtained was stored in air tight poly bags and used for preparation of extract.

\section{Preparation of extract}

The cold extraction procedure was used for extracting leaves with solvents as per the procedure adopted by Prakash and Karmegam (2012) and Vigneshwari et al., (2014). The leaves collected were transported to the laboratory for further processing. The leaves of the plants collected were individually washed with tap water, blotted with filter paper and spread over newspaper for air drying under shade. After complete dryness, the leaves of individual plants were powdered using a mixer grinder. A known quantity of leaf powder (100 g) of each plant leaves was taken in a $250 \mathrm{ml}$ conical flask and added with 100-200 $\mathrm{ml}$ of ethanol individually. The solvent-leaf powder mixtures were kept at room temperature for $48 \mathrm{hrs}$ and rapidly stirred using glass rod every $8 \mathrm{hrs}$. After $48 \mathrm{hrs}$, the extract of each plant was filtered through Whatmann No.1 filter paper to exclude the leaf powder. Then each filtrate was kept in beaker on a water bath at $45^{\circ} \mathrm{C}$ until the solvent gets evaporated. A greasy final material (crude extract) obtained for each plant was transferred to screw cap tubes and stored under refrigerated condition till use.

\section{DPPH radical scavenging activity}

DPPH radical scavenging activity was carried out by the method of Molyneux, (2004). To $1.0 \mathrm{ml}$ of $100.0 \mu \mathrm{M}$ DPPH solution in methanol, equal volume of the test sample in methanol of different concentration was added and incubated in dark for 30 minutes. The change in colouration was observed in terms of absorbance using a spectrophotometer at $514 \mathrm{~nm} .1 .0 \mathrm{ml}$ of methanol instead of test sample was added to the control tube. Different concentration of ascorbic acid was used as reference compound. Percentage of inhibition was calculated from the equation [(Absorbance of control - Absorbance of test)/Absorbance of control)] X 100. IC50 value was calculated using Graph pad prism 5.0.

\section{Results and discussion}

The results of the present study on DPPH radical scavenging activity of ethanolic leaf extracts of the medicinal plants, Capparis sepiaria, Euphorbia heterophylla and Tamilnadia uliginosa showed promising results in comparison with the standard (vitamin C) as shown in Table 1. The Among the three different leaf extracts used, ethanolic leaf extract of Tamilnadia uliginosa showed higher DPPH inhibition activity at $75(\mu \mathrm{g} / \mathrm{ml})$ concentration followed by Capparis spinosa and Euphorbia heterophylla 
respectively. The ethanolic crude extract of Tamilnadia uliginosa leaves showed the inhibition activity of $20.1 \pm 2.4,37.8 \pm 2.9,49.3 \pm 3.7,60.5 \pm 5.1$ and $77.6 \pm 4.5 \%$ respectively in 15, 30, 45, 60 and $75 \mu \mathrm{g} / \mathrm{ml}$ (Fig. 1). Following Tamilnadia uliginosa, the ethanolic leaf extract of Capparis sepiaria showed good DPPH inhibition activity (Fig. 2) and the least inhibition activity was observed in Euphorbia heterophylla leaf extracts (Fig. 3). In all the extracts, the DPPH activity was found to be concentration dependent.

Table.1 DPPH radical scavenging activity of ethanolic leaf extract of medicinal plants

\begin{tabular}{|c|c|c|c|c|c|}
\hline \multicolumn{2}{|c|}{ Standard vitamin $\mathrm{C}(\mu \mathrm{g} / \mathrm{ml})$} & \multicolumn{4}{|c|}{ DPPH percentage of inhibition } \\
\hline $\begin{array}{l}\text { Concentration } \\
(\mu \mathrm{g} / \mathrm{ml})\end{array}$ & $\%$ of inhibition & $\begin{array}{l}\text { Concentration } \\
(\mu \mathrm{g} / \mathrm{ml})\end{array}$ & ELCS & ELEH & ELTU \\
\hline 15 & $22.8 \pm 0.4$ & 15 & $13.2 \pm 2.9$ & $11.7 \pm 1.9$ & $20.1 \pm 2.4$ \\
\hline 30 & $45.0 \pm 0.5$ & 30 & $30.6 \pm 4.2$ & $20.3 \pm 1.6$ & $37.8 \pm 2.9$ \\
\hline 45 & $53.4 \pm 0.3$ & 45 & $43.1 \pm 3.5$ & $29.5 \pm 2.2$ & $49.3 \pm 3.7$ \\
\hline 60 & $68.6 \pm 0.6$ & 60 & $50.5 \pm 4.3$ & $35.8 \pm 2.3$ & $60.5 \pm 5.1$ \\
\hline 75 & $83.2 \pm 0.5$ & 75 & $61.8 \pm 4.7$ & $40.2 \pm 2.8$ & $77.6 \pm 4.5$ \\
\hline
\end{tabular}

Note: EL - Ethanolic leaf extract; CS - Capparis sepiaria; EH - Euphorbia heterophylla; TU - Tamilnadia uliginosa.

Fig.1 DPPH radical scavenging activity of ethanolic exctract of Capparis sepiaria leaves. Error bars indicate \pm SD

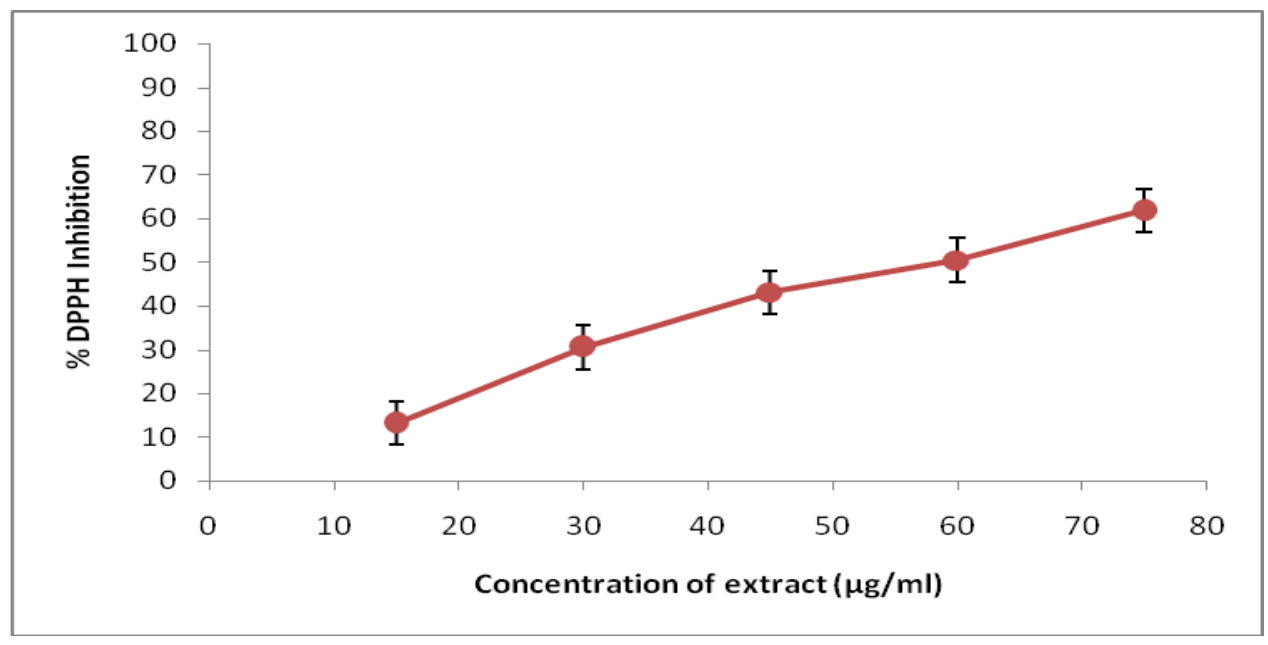

Fig.2 DPPH radical scavenging activity of ethanolic exctract of Euphorbia heterophylla leaves

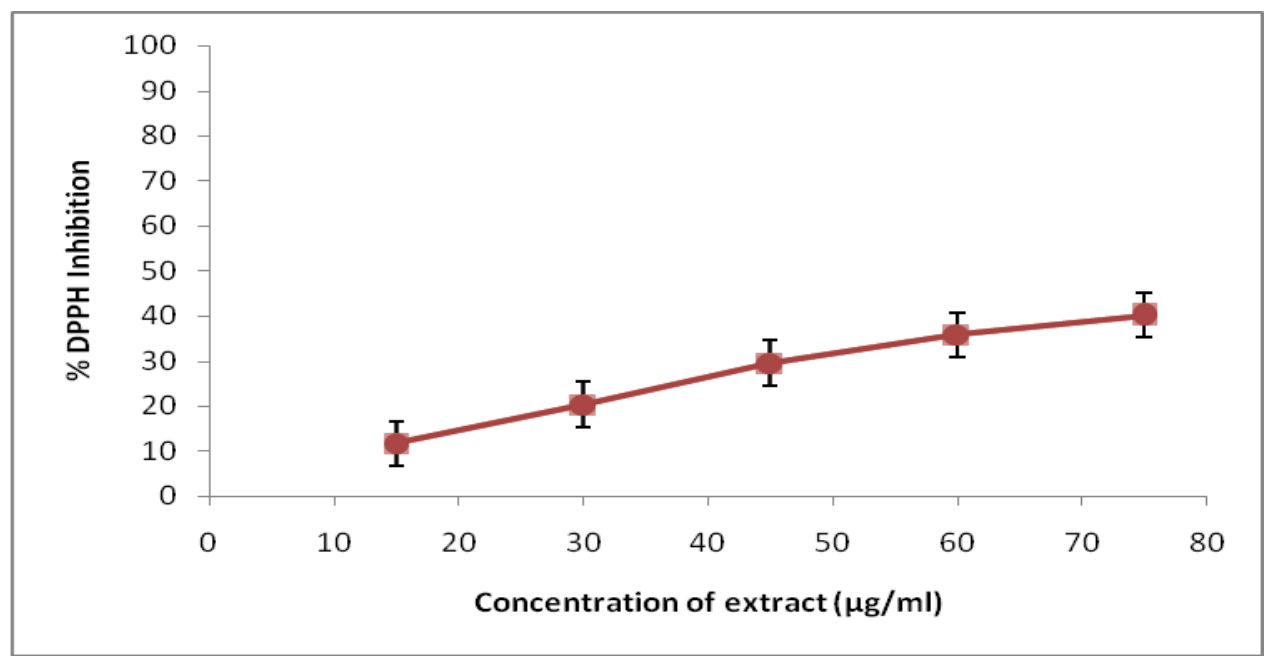


Fig.3 DPPH radical scavenging activity of ethanolic exctract of Tamilnadia uliginosa leaves

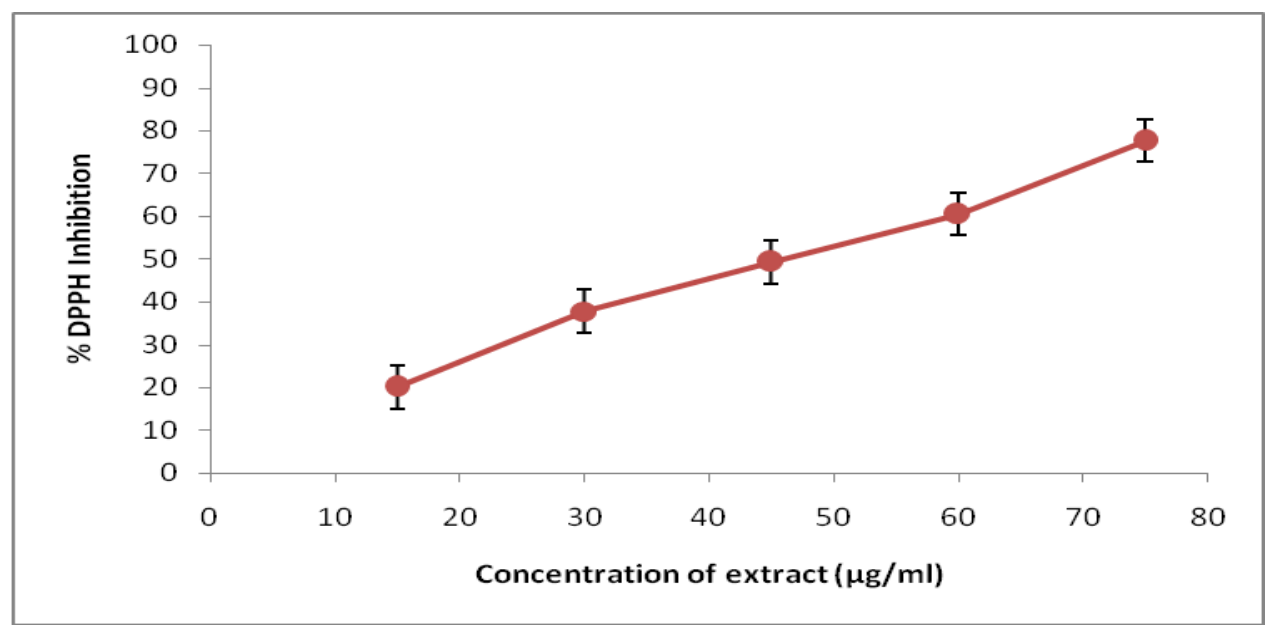

It has been well known that the phytochemical components present in the plant extracts exert various biological activities, among which antioxidative effect is well pronounced. The in vitro results clearly establish the possibility that polysaccharides extracted from Bryopsis plumosa could be effectively employed as ingredient in health or functional food, to all deviate oxidative stress. However, comprehensive studies need to be conducted in experimental animal models (Song et al., 2010). Recent proof shows that plant polyphenols exhibit antioxidant and radical scavenging properties. By three separate and complementary methods - DPPH assay, h-carotene linoleic acid assay and NBT-reduction assay it was established that a polyphenol-rich extract from the medicinal plant Geranium sanguineum L. With strong anti-influenza virus activity, possessed antioxidant and radical scavenging capacities (Sokmen et al., 2005).

The DPPH radical scavenging activity studies revealed that ethanol extracts of leaves of Tamilnadia uliginosa exhibited higher radical scavenging activity of $77.6 \pm 4.5 \%$ followed by the extracts of Capparis sepiaria $(61.8 \pm 4.7 \%)$. Ethanol leaf extract of Tamilnadia uliginosa was found to possess considerable DPPH radical scavenging activity in comparison with standard (vitamin C). The studies on phytochemicals in Tamilnadia uliginosa may provide further insights in its activity.

\section{References}

Gamble, J.S., Fischer, C.E.C., 1957. Flora of the Presidency of Madras (Vols. I-III). Authority of Secretary of State for India in Council, London. 1389 p.
Kalpana, B., Prakash, M., 2015. Antibacterial activity of Capparis sepiaria L. (Capparidaceae) leaves and fruits. Int. J. Curr. Microbiol. App. Sci. 4(1), 10071012.

Kalpana, B., Prakash, M., 2016. Antibacterial activity of leaf extracts of Euphorbia heterophylla L. and Tamilnadia uliginosa (Retz.) Tirveng. \& Sastre against Xanthomonas campestris pv. citri. Int. J. Curr. Res. Biosci. Plant Biol. 3(1), 135-138.

Khattak, K.F., Simpson, TJ. 2010. Effect of gamma irradiation on the antimicrobial and free radical scavenging activities of Glycyrrhiza glabra root. Radiat. Phys. Chem. 79: 507-512.

Lewinsohn, E., Mark Gijzen. 2009. Phytochemical diversity: The sounds of silent metabolism. Plant Sci., 176: 161-169.

Madhavi, D. L., Deshpande, S. S., Salunkhe, D. K. 1996. Food Antioxidants: Technological, Toxicological, Health Perspective. New York: Marcel Dekker., pp. $1-5$.

Matthews, K.M., 1983. The Flora of Tamil Nadu Carnatic, St. Joseph's College, Tiruchirappalli, Tamil Nadu, India. $1034 \mathrm{p}$.

Molyneux, P., 2004. The use of the stable free radical diphenyl picrylhydrazyl (DPPH) for estimating antioxidant activity. J. Sci. Technol., 26: 211-219.

Prakash, M., Karmegam, N., 2012. In-vitro antibacterial activity of certain plant extracts against plant disease causing bacteria isolated from citrus plant. Int. J. Curr. Microbiol. App. Sci. 1(1), 1-11.

Satyanarayana, T., Mathews, A. A., Anjana Male, Ch. K. V. L. S. N., Surendra, G., 2010. Screening of antiinflammatory and antimicrobial activities of stem extract of Capparis sepiaria Linn. Res. J. Pharmaceut. Biol. Chem. Sci. 1(3), 330-336. 
Shyur, L. F., Tsung, J.H., Chen J.C., Chiu, C.Y., Lo, C.P. 2005. Antioxidant properties of extracts from medicinal plants popularly used in Taiwan. Int. J. App. Sci. Engg., 3: 195-202.

Silva, C.G., Herdeiro, R.S., Mathias, C.J., Panek, A.D., Silveira, C.S., Rodrigues, V.P., Renno, M.N., Falcao, D.Q., Cerqueira, D.M., Minto, A.B.M., Nogueira, F.L.P., Quaresma, C.H., Silva, J.F.M., Menezes, F.S., Eleutherio, E.C.A. 2005. Evaluation of antioxidant activity of Brazilian plants. Pharmacol. Res., 52(3):229-233.

Sokmen, M., Maria Angelova., Ekaterina Krumova., Svetlana Pashova., Stefka Ivanchevac., Atalay
Sokmend., Julia Serkedjieva. 2005. In vitro antioxidant activity of polyphenol extracts with antiviral properties from Geranium sanguineum L. Life Sciences. 76: 2981-2993.

Song, H., Quanbin Zhang. Zhongshan Zhang, Jing Wang. 2010. In vitro antioxidant activity of polysaccharides extracted from Bryopsis plumosa. Carbohydrate Polymers. 80: 1057-1061.

Vigneshwari, C., Nagaraj, R., Karmegam, N., 2014. Synergistic anti-Staphylococcus aureus (methicillin resistant) activity of ethnomedicinal plants from Shevaroy hills (Eastern Ghats), south India. Int. J. Curr. Res. Biosci. Plant Biol. 1(2), 51-59.

\section{How to cite this article:}

Kalpana B. and Prakash M. 2017. DPPH Radical Scavenging Activity of Ethanolic Leaf Extracts of Capparis sepiaria, Euphorbia heterophylla and Tamilnadia uliginosa. Int.J.Curr.Res.Aca.Rev. 5(12), 10-14.

doi: https://doi.org/10.20546/ijcrar.2017.512.002 